\title{
The performance and the effects of family control in North African IPOs
}

\section{Introduction}

There is a considerable literature focussing on firm performance attributes and the effects of family control on underpricing in Initial Primary Offerings (IPOs) from the initial flotation of shares on stock exchanges. However the overwhelming majority of this is focussed on IPOs within the developed markets of Europe (Kaserer and Molderhauer, 2008), in North America and Australia (Bartholomeusz and Tanewski, 2006) and even the developing markets of Asia such as Taiwan (Filatotchev et al, 2005) and Thailand (Bertrand et al, 2008) with little if any attention on the North African region. This region is notable from its proximity to Europe and its having been heavily influenced through the transplantation of French civil code law institutions during the course of the nineteenth century while having a business environment and political economy largely shaped by Islamic principles reinforced by dominant extended family groups and pyramidal ownership (North (1991); Kuran (2004)).

While North African legal and governance systems are modelled on French civil code law institutions promoting the centralised authority and property rights of the state in preference to those of individual minority interests (Hayek, 1960) there are considerable differences with Morocco, Tunisia and Algeria having benefitted from institutional development occurring in France itself while Egypt was somewhat left behind owing to a more recent colonial relationship with the British empire (Kuran, 2004). However institutional development in North Africa is largely unique in having been necessitated through the need to compete with European firms on lucrative trans-Mediterranean trade routes rather and in having benefitted from sizeable European populations rather than from institutional imposition by an outside and culturally distant colonial metropole (Kuran, 2003). Thus a secular civil code judiciary passed law through legislative acts and outlining of "bright line rules" on commercial contract resolution (Levine, 2005) arising from a business community that largely adheres to traditional Islamic beliefs (Kuran, 2004). This process of successful adoption and transplantation of civil code institutions into the deeper societal institutional matrix is a critical determinant in ensuring the commercial competitiveness of the economy (Williamson, 2000). Given the comparatively weaker protection of property rights in civil code countries as opposed to those adhering to common law ((La Porta et al (2000); Beck et al (2003)) and the consequent high private benefits of control and decreased protection of property rights with the dominant underlying Islamic cultural traditions favouring extended family networks and partnerships listings on Maghreb stock exchanges are typically made up from either former state owned enterprises (SOEs) or familycontrolled small and medium enterprises (SMEs) (El Mehdi (2007); Dahawy (2007)). This is particularly evident as the traditional forms of organizational entity available to entrepreneurs under 
classical Islamic commercial law were proprietary operations, family ventures and traditional Islamic partnerships (Kuran, 2003).

The concept of underpricing in the flotation of new stock represents a direct wealth transfer from the founders and initial shareholders to new external investors (Filatotchev and Bishop, 2002) but its extent can be significantly influenced by the extent of protection of property rights over a financial security's entitlements to corporate cash flows, whether these are enshrined in the prevailing legal system (La Porta et al, 1998 henceforth LLSV), or through optimal corporate governance mechanisms (La Porta et al, 2000). However while La Porta et al (1997) first characterised differences in ownership concentration across countries with those of civil code as opposed to common law being dominated by insiders with less dispersion LLSV found evidence across a sample of 49 countries that property rights and minority investors were best protected in common law systems followed by Scandinavian and German civil codes and least in French civil systems. As such corporate governance is a set of mechanisms more concerned in the protection of outside investors from expropriation by corporate insiders (La Porta et al, 2000). This has a number of implications in the monitoring and surveillance of insiders with a unitary supervisory board structure composed of representatives of major shareholders being favoured in civil code countries where legal protection of property rights is weaker, incentives to expropriate outsiders higher, and participation of minority investors discouraged (Jensen and Meckling (1976); La Porta et al, 1999; 2000). Consequently governance practices such as split boards and separation of the roles of CEO and Chairman as well as more diversified ownership are not common in civil code law countries in contrast to their common law counterparts (La Porta et al, 2000). The civil code legal system engenders economic structural rigidities where internal and relationship-based forms of finance and associated corporate governance supersede external market-driven forms of finance and firm-governance structures of common law countries (Levine, 2005). The level of economic rigidity engendered by the legal institutions also infers that market-determined outcomes to firm governance are at best unlikely (Levine, 2005) with ownership structure being much less likely to adapt to pressures from investors searching for value gains as is the case in Germany (Kaserer and Moldenhauer, 2008). Furthermore this inertia in ownership is enhanced given the business environment is dominated by large family blockshareholders and an often extensive network of family cross-holdings between family groups within North Africa (Dahawy (2007); El Mehdi (2007)). As a consequence of these structural rigidities and ownership characteristics Kaserer and Moldenhauer (2008) assert that the firm performanceownership relationship is likely to be less susceptible to endogeneity than in common law countries with legal institutions promoting external finance and well developed financial markets.

The literature concerning the development of agency theory in the context of family firms is largely divided with proponents advocating benefits of concentrated family ownership on firm value and performance (see Fama and Jensen (1983)) and those citing evidence to the contrary such as 
Claessens et al (2000). The literature focussing on the former argument that increased concentration of family ownership promotes firm value and performance is largely centred on the propositions of incentive alignment and altruism. Fama and Jensen (1983) first established the incentive alignment motivation of family groups acting as both principals and agents and in so doing reducing agency costs, such as monitoring and governance, through a central alignment of interests towards to the common welfare and benefit of the family as a whole. Furthermore Chami (1999) find evidence that family firms engage in decision-making over longer investment-time horizons than conventional shareholders which is in line with the family perceiving the firm itself as an asset for intergenerational wealth transfer between generations in the same family. Increased coordination between and within family groups with specialisation in particular trades or skills also acts to reduce governance and monitoring costs (Bartholomeusz and Tanewski, 2006) and act as an incentive for founding families in the transfer of human, social and financial capital between generations (McConaughty et al, 2001). However while many of these factors act in defining the incentive alignment in families that leads to reduced monitoring costs they also promote the concept of altruism which is defined as a phenomenon that occurs when an individual pursues self-interested goals attained through the promotion of welfare goals of others (Bergstrom (1995); Becker (1981)). Bartholomeusz and Tanewski (2006) cite that this concept of altruism within a family social network acts to promote loyalty, communication and longer investment-time horizons in decision-making that collectively act to reduce agency costs. However there is a literature detailing a contrasting view advocating the concentrated family ownership is detrimental for firm value and increases agency costs (Shleifer and Vishny (1997); Claessens et al (2000)). While increased ownership and control infer the potential for families to expropriate wealth from other shareholders through excessive compensation (Morck et al, 2000), engagement of wasteful projects and cronyism (Claessens et al, 2000), and special dividends (Perez-Gonzalez, 2002), there is a heightened possibility of pyramidal control facilitating expropriation of wealth to family owned subsidiaries (Anderson et al, 2003). Furthermore Schulze et al (2001) find evidence that family shareholders are able to hold non-family shareholders to ransom in the presence of small illiquid financial markets where a forced sale would likely be at a less than fair value as well as in systems with poor protection of property rights where inefficient social contracting would be promoted. As such collectively these issues relate the concept of altruism to negative outcomes in terms of the relationship between concentrated family ownership and firm value and performance.

This paper extends the previous research by several ways. Firstly it extends the study of agency costs in family firms by investigating levels of IPO underpricing across North African equity markets in relation to levels of family ownership concentration, where the structural rigidity engendered by civil code law systems infers that endogeneity will likely be less of an issue. Secondly it explores the impact of board size and levels of concentrated family control and ownership in the 
board as opposed to across the entire firm in underpricing. Finally we look at the determinants of family ownership itself and the relationship between family ownership levels and that of other major block-shareholder types and firm control factors.

\section{Data}

This paper represents a comprehensive list of all IPOs undertaken on each of the national stock exchanges of the North African region, namely Algeria, Egypt, Morocco and Tunisia for the period 2000 and 2009. The evidence in Table 1 reveals that listing activity is sporadic owing to the smaller size of these markets with large periods of inactivity such as between 2000 and 2005 in Egypt and 2000 and 2004 in Morocco. The smallest of the exchanges, Algeria, has failed to attract any listings since the period immediate following its inception in 1999. Tunisia in contrast has had a very small but steady stream of listings over the sample period. Consequently a total of 63 IPOs are included in the sample period.

\section{Table 1}

Flotation prospectuses were hand-collected from financial market regulator websites for Algeria and for Morocco while a combination of Thomson Corporation Perfect Information and Al Zawya databases were used to source Egyptian prospectuses. Al Zawya database, the national stock exchange and direct contact with individual firms were used to source prospectuses for Tunisia. We exclude readmissions and transfers of listings between main and development boards while also excluding demergers, reorganizations and flotations of preferred stock, convertibles, unit and investment trusts. Consequently our final sample is composed of 63 IPO firms that floated ordinary shares with single class voting rights. Share prices were obtained from Bloomberg, DataStream and $\mathrm{Al}$ Zawya as well as direct from the national stock exchange in Algeria. US\$ Exchanges rates were obtained from Bloomberg.

\section{Methodology}

This study is primarily focussed on the elucidation of the relationship between IPO firm underpricing and family and firm governance characteristics as well as family and corporate block-shareholder ownership. The determinants of family ownership are investigated while the study is extended to assess the factors influencing whether the controlling family retains effective management of the firm.

\subsection{Underpricing}

Initial returns are used as a measure of underpricing. Two variants are used, namely that in 2 weeks and then 4 weeks following listing on exchange. This is due to concerns over the severity of illiquidity in North Africa's equity markets causing price-rigidity (Smith, 2005) that in turn would 
inhibit the movement of prices in relation to their ability to reflect order flow and information (O’Hara, 2003). In line with Filatotchev and Bishop (2002) underpricing is calculated as the difference between stock price at 2 (or 4 ) weeks and the issue price divided by the issue price:

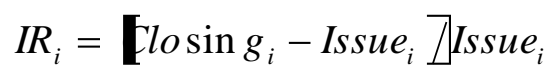

\subsection{Board governance impact on performance}

The mainstream international corporate governance literature views an IPO as being the first major "liquidity event" in the life cycle of fast growing firms when founders and initial investors (corporate insiders) begin the process of realizing the value of their ownership stake in the firm (Brav and Gompers, 2003). However the IPO process introduces a number of potential agency conflicts for the various principal and agent parties involved (Bruton et al, 2009). Adverse selection and moral hazard problems arise from the asymmetric information between new owners (investors) and incumbent managers (agents) as there are incentives for the latter to mislead or even worse expropriate the former (Bruton et al (2009); Boulton et al (2009)). It is this relationship between ownership of large controlling blocks or family groups and levels of asymmetric information, reflected by the level of underpricing, as well as firm value and performance that has been the subject of considerable controversy with a strong divide emerging in the literature (Chu, 2009).

The divide in the literature concerning the effects of these dominant family groups on governance and firm performance is highlighted with a considerable body of evidence showing the detrimental effects of altruism and the promotion of family interests over and above those of nonfamily members on firm performance while a contrasting body draws on the benefits of incentive alignment between principals and agents and a reduction in agency cost thereby boosting firm performance. Research concerning the former negative association is further divided into applications of agency theory concerning the link between concentrated family ownership and expropriation of wealth (Morck et al (1998); Smith and Amoako-Adu (1999)) and an institutional overlap literature (Chu, 2009) concerning the misalignment between business and family "institutions". Agency theory arguments are commonly centred on the proposition that the identity of concentrated owners is closely linked to their incentive, skill, and objectives in monitoring the firms management (Thomsen and Pedersen, 2000). Furthermore family members acting as shareholders and managers are likely to have less well defined or even unclear roles and responsibilities over and above membership of the family social network itself (Kets de Vries, 1993). The likelihood of family members having substantial control of cash flow rights combined with their collective altruistic motivations infers that their objectives will be focussed more on the longer term survival and growth of the firm rather than profit maximisation for minority and institutional shareholders (Thomsen and Pedersen, 2000). Finally concentrated family control acts to shield the firm from disciplinary effects 
of the market for corporate control as there are reduced possibilities for hostile takeovers (Barclay and Holderness (1989); Gomez-Mejia (2003)). The focus of the institutional lens concerns the very different sets of norms and social values enshrined in the two very different types of institution, namely that of the business and that of the family (Lansberg, 1983). Family as an institution places maximum emphasis on the organizational design to maximise resource allocation in accordance with social ties, personal trust and established loyalties to promote family members (Kepner, 1983). In contrast the business institution places emphasis on the optimal managerial organizational structure to promote firm performance and maximise value for shareholders. The altruistic nature of families infers that recruitment will primarily occur from within the family itself which is a limited talent pool (Andersen and Reed, 2003) and there will be an emphasis on family succession and inheritance (Brenes et al, 2006). These factors are deemed likely to reduce the competitiveness of family firms and exert a negative impact on firm performance and shareholder value (Brenes et al (2006); Carney (1998)).

More recently the literature relating concentration of family ownership to enhanced firm performance and value has emerged citing issues such as incentive alignment between principals and agents that reduces monitoring costs (Andersen and Reeb, 2003) and the benefits of extended family networks in internalising markets and reducing transactions costs (Filatotchev and Bishop, 2002). Moreover some of the factors associated in the traditional literature regarding a negative association between concentrated ownership and performance are seen as inferring positive association such as family members emphasis on longer term growth and survival of the firm, which is a feature of good governance, rather than being solely focussed on short-term interests of self-interested shareholders (Bruton et al, 2003). Further evidence relating to the benefits of concentrated family ownership of firms concerns the reinvestment of wealth back into the firm by family members who have their own personal incentives aligned with those of the wider family social network and firm (Andersen and Reeb, 2003) and considerably fewer moral hazard problems with less asymmetric information than non-family firms (Andersen and Reeb, 2003). An additional literature strand of agency theory cites that control requires information which is costly to acquire (Andersen and Reeb, 2003). Family members are often in informational advantageous positions relative to non-family members owing to having often been in contact with the business since childhood (Kets de Vries, 1993) making the control and monitoring of family firms easier than non-family firms (Smith and Amoako-Adu, 1999). These information advantages held by family shareholders also create advantages in disciplining possible opportunistic behaviours by agent-managers and minimizing problems associated with freeriding inherent with small individual shareholder (Demsetz and Lehn, 1985). Burkart et al (2003) find empirical evidence supporting the retained ownership of families which provides these firms with a competitive advantage. Equally there is evidence of the benefits arising from the sustained presence of extended family control and concentrated ownership within firms where from a resource- 
based perspective these act as intangible and specific resources facilitating long term relations with stakeholders such as buyers, employees, suppliers and banks (Poza, 2007). These extended long term family orientated relationships reduce transactions costs thereby resulting in better monitoring both within and between firms (Filatotchev et al, 2005). This is an especially important benefit of family governance mechanisms in environments characterised by weak protection of property rights, high transactions costs and considerable transactions costs associated with information collection and verification (Filatotchev et al, 2005). There is also considerable reputational capital at stake with family firms as these families often have significant social status within the national political economy (DeAngelo and DeAngelo, 2000) which leads to a wider alignment of incentives on a principal-principal basis where family incentives are aligned with those of broader society and political motivations (Chu, 2009).

As such we would expect that the relationships between the size of boards of directors and the degree of independence of boards of directors to have different effects on underpricing between family and non-family firms. The enhanced monitoring effect arising from having a separate and distinct independent board of directors supervising the lower executive board would be expected to have a positive impact on underpricing for non-family firms while having a negative effect on underpricing for family firms. This is intuitively expected as family firms have less incentive to create split boards in relation to their ability to monitor incumbent managers in relation to the preexisting family mechanisms for information revelation and disclosure. As such investors are faced with lower levels of asymmetric information and less underpricing in the context of family firms with a single tier board structure rather than from non-family firms that have split boards and a lack of the family-based altruistic mechanisms for disclosure and protection of property rights. While there are likely differences between the ratio of independent to non-independent directors larger size boards are likely to increase asymmetric information owing to less coordination between principals and agents. Consequently I test the following hypotheses:

H-1.1: Board size is positively associated with IPO-firm underpricing in family firms

H-1.2: Board size is positively associated with IPO-firm underpricing in non-family firms

H-1.3: Board independence is negatively associated with IPO-firm underpricing in family firms

H-1.4: Board independence is positively associated with IPO-firm underpricing in non-family firms

OLS regressions were used to test these hypotheses using unbalanced panels. This takes the form: 
Underpricing $_{i}=$ Cons $\tan t+\beta_{\text {Governance }}$ Governance $+\beta_{\text {Firm }}$ Firm Controls

$+\beta_{\text {IPO }}$ IPO Controls C $_{i}$

Board size is defined as the natural logarithm of the absolute number of directors. Board independence is the ratio of the number of independent (non-executive) directors to executive directors. In the case of supervisory boards then the count of executive directors is the taken as the number of executive-level senior management detailed in the prospectus.

Where governance represents each of the parameters indicated in the hypotheses and Firm and IPO controls are introduced from the literature. Firm-level controls used in each case included firm size, the natural logarithm of tangible assets as expressed in US\$, firm age, expressed as the natural logarithm of age, itself defined as the number of years from foundation to IPO (Filatotchev and Bishop (2002); Filatotchev et al (2005)). Equally given debt may have a governance role limiting the level of managerial discretion and mitigating potential agency conflicts (Bruton et al, 2009). As such I control for possible effects of debt on IPO valuations in using the total debt-to-total asset ratio. Given the inclusion of a very wide variety of firms undergoing IPOs ranging from the privatizations of very large former state owned enterprises to smaller high growth technology companies with considerable variation in revenues this is controlled for by the natural logarithm of US\$ converted revenues in IPO year. We introduce IPO-related controls and two specific variables to control for the size of the offering, given the considerable dispersion of amounts raised in IPOs, with the natural logarithm of the ratio of IPO proceeds to total assets and tangible assets respectively, where all values are expressed in US\$.

\subsection{Lead manager effects on IPO firm underpricing}

The effects of the lead manager on IPO firm underpricing is an under-researched area despite the emergence of studies focussing on the roles of underwriters in flotation's (Boulton et al, 2009). Lead managers are of particular significance in civil code and especially in Francophone markets where the formal role of Chef de File is broader in its remit than the role of lead manager in Anglophone markets. Consequently the enhanced reputational effects from the employment of either a market leading or foreign Lead Manager is likely to have a significant effect in signalling quality and as such on decreasing levels of IPO underpricing. Consequently I test the following hypotheses:

H-2.1: Lead Manager reputation is negatively associated with IPO-firm underpricing in family firms

H-2.2: Lead Manager reputation is negatively associated with IPO-firm underpricing in non-family firms 
H-2.3: Presence of Foreign Lead Manager is negatively associated with IPO-firm underpricing in family firms

H-2.4: Presence of Foreign Lead Manager is negatively associated with IPO-firm underpricing in non-family firms

OLS regressions were used to test these hypotheses using unbalanced panels. This takes the form:

Underpricing $_{i}=$ Cons $\tan t+\beta_{\text {Lead }}{\text { Lead Manager }+\beta_{\text {Firm }} \text { Firm Controls }}_{i}$

$+\beta_{\text {IPO }}$ IPO Controls C $_{i}$

Lead Manager reputation is constructed as the cumulative market share defined as the ratio of total amount raised by firms with that particular lead manager to the total raised across the market. This construction is similar to that for underwriter reputation in studies such as Boulton et al (2009) although in civil code markets the lead manager, or chef de file frequently has a role responsibilities beyond those of a simple lead manager. Lead manager foreign is a simple pulse dummy variable assuming value 1 if lead manager was foreign and 0 otherwise. These two lead manager variables control for any possible signalling effects to external investors through the selective employment of particular lead managers. Firm and IPO control variables are defined as in preceding section.

\subsection{Business Angel and Private Equity effects on IPO firm underpricing}

The signalling effects of external business angel and private equity investors in terms of quality and the consequent reduction of asymmetric information between principals and agents has received limited attention in the literature (Chahine et al, 2007). Leading from the initial research undertaken by Chahine et al (2007) I conjecture that the informal relationship-based finance of business angels will cause a reduction in asymmetric information and underpricing owing to business angel finance arising from an extension of family networks within the wider Maghreb economy. However in contrast to this informal network relationship finance the more formal organised, and often foreign, private equity and venture capital investment will result in an increase in underpricing (Chahine et al, 2007). Consequently I test the following hypotheses:

H-3.1: The presence of Private Equity is positively associated with IPO-firm underpricing in family firms

H-3.2: The presence of Private Equity is positively associated with IPO-firm underpricing in nonfamily firms 
H-3.3: The presence of Business Angels is negatively associated with IPO-firm underpricing in family firms

H-3.4: The presence of Business Angels is negatively associated with IPO-firm underpricing in nonfamily firms

OLS regressions were used to test these hypotheses using unbalanced panels. This takes the form:

Underpricing $_{i}=$ Cons $\tan t+\beta_{\text {Investor }}$ Investortype $+\beta_{\text {Firm }}$ Firm Controls

$+\beta_{\text {IPO }}$ IPO Controls C $_{i}$

Dichotomous pulse dummy variables, taking value 1 should a condition be satisfied and 0 otherwise, are introduced to categorize particular types of investor i.e. whether business angel or private equity/ venture capital. These involve detailed analysis of the ownership cited in prospectuses and subsequent investigation as to the nature of entities outlined using internet based sources such as corporate web-pages or local market financial regulators. Firm and IPO controls are as defined in preceding sections.

\subsection{Family control effects on performance}

The North African regional business environment as a whole is characterized by a mix of former SOEs and SME family-firms that commonly form the backbone of national economies in the Maghreb (OECD (2007); Hearn et al (2009)). Chu (2009) cites evidence of the benefits arising from the overlap of responsibilities between owners and incumbent managers that can lead to streamlines and efficient monitoring processes, reduced administrative costs, fast decision-making, investment efficiency and longer time horizons for the measurement of firm performance. A unique characteristic of family-firms is the ability of family members to transcend across the divide between owners (principals) and managers (agents) which underlines the governance mechanism in familyfirms. However Poza (2007) argues that this mechanism is only as good as the quality of interaction between business and family and that this is influenced by the size of the firm. Furthermore Poza (2007) asserts that smaller family firms are better able to maintain the communication interface between business and family and capture the resulting benefits in terms of improved firm performance, monitoring and reduction in asymmetric information.

These arguments would suggest that the interface between family and business is critical in information transmission, monitoring and the exercise of control. While size affects this relationship, the specific nature of how size affects this relationship is through improved coordination between 
business and family interests leading to better communication within the firm. As such we extend these arguments in focussing on board structure within family firms:

H-4.1: The ratio of family members on board of directors to total number of family members associated with firm is negatively associated with IPO-firm underpricing

H-4.2: The ratio of family board-member ownership to total family ownership is negative associated with IPO-firm underpricing

OLS regressions were used to test these hypotheses using unbalanced panels. This takes the form:

$$
\begin{aligned}
& \text { Underpricing }_{i}=\text { Cons } \tan t+\beta_{\text {Family }} \text { Family Conc. }+\beta_{\text {Firm }} \text { Firm Controls } \\
& +\beta_{I P O} \text { IPO Controls } s_{i}+\varepsilon_{i}
\end{aligned}
$$

Family concentration is either of the two variables: ratio of family board members to total family involvement and ratio of family board-level ownership to total family ownership. The first is a simple ratio of the number of family board-level personnel in relation to the total number of family members associated with the firm, whether these are shareholders or supervisors and lower-level management, with all detailed in prospectus. The second is constructed from the total shareholdings of family board members against the total family ownership, the construction of which is outlined above. Firm and IPO control variables are as defined in previous sections.

\subsection{Determinants of Family ownership}

Given the importance of family-firms to the North African regional economy and their propensity in stock exchange listings it is important to elaborate on the determinants of family ownership. Levels of concentrated family ownership will be more likely determined by the governance structure within the firm and intrinsic firm factors (Chu, 2009). Much of the strength of continued family ownership is derived from deep collective knowledge and involvement of the firm which would be otherwise lost if outside block-shareholders such as private equity and venture capitalists or business angels became involved (Kaserer and Moldenhauer, 2008). Consequently we extend these arguments:

H-5.1: The ratio of family board members to total family involvement in the firm is negatively associated with family share ownership

H-5.2: The presence of business angels is negatively associated with family share ownership 
H-5.3: The presence of private equity and venture capitalists is negatively associated with family share ownership

OLS regressions were used to test these hypotheses using unbalanced panels. This takes the form:

$$
\begin{aligned}
& \text { Family Ownership }_{i}=\text { Cons } \tan t+\beta_{\text {Variables }} \text { Variables }+\beta_{\text {Firm Controls }} \text { Firm Controls } \\
& +\beta_{\text {Ownership }} \text { Ownership } \\
& i
\end{aligned}
$$

Where variables represents the dichotomous pulse dummy variables indicating the retained presence of private equity/ venture capital and business angels. The ratio of family board members to total family participation in the firm is defined as number of family board members to total number of family member involved in the firm. Firm controls are defined in preceding sections while ownership represents a set of variables defined as post-IPO executive, non-executive and block-shareholder levels of retained ownership. These additional ownership control variables are used to counter for potential signalling effects post-IPO through the retained ownership by certain insider groups such as board level directors who have considerable oversight over corporate affairs (Filatotchev and Bishop (2002); Filtatochev et al (2005)).

\subsection{Family and corporate block ownership effects on performance}

The role of family and corporate block-shareholder ownership and the level of asymmetric information reflected in underpricing is a source of conjecture in the literature. There is considerable evidence from Boulton et al (2009) and Levine (2005) regarding the continued presence of corporate insiders or block-shareholders in markets with weaker levels of investor protection which is an inherent feature of civil code legal regimes. Similarly there is evidence from the continued presence of family ownership in the reduction of asymmetric information and underpricing (Filatotchev et al (2005); Chu (2009); Kaserer and Moldenhauer (2008)). As a consequence I test the following hypotheses:

H-6.1: Family ownership is negatively associated with IPO-firm underpricing in IPO firms

H-6.2: Corporate block-shareholder ownership is negatively associated with IPO-firm underpricing in IPO firms

The testing of these hypotheses is complicated given the presence of endogeneity issues and the potential for reverse causation between levels of family and block-shareholder ownership and underpricing and vice-versa. However while this is of particular concern in developed markets that 
commonly adhere to common law the less developed nature of civil code markets and in particular those of the North African nations infers that market-determined outcomes of levels of ownership are less likely (Filatotchev et al (2005); Kaserer and Moldenhauer (2008)). As such the degree of reverse causation and feedback between variables is somewhat mitigated.

Given the considerable consternation regarding these endogeneity issues the employment of two stage least squares (2SLS) techniques using instruments variables is preferable to the standard OLS methods. To test for endogeneity in the model, the method of Generalised Instrumental Variable Estimation (GIVE) is used. Firstly each of the potentially endogenous variables is individually regressed on a set of available instruments and the truly exogenous variables in the model. These represent a series of single reduced form or artificial equations, where the instruments are variables chosen for their lack of correlation to the dependent variable (underpricing) in the original 2SLS model. Then the $\mathrm{Wu}$-Hausman procedure is used to identify which variables are endogenous, correcting with instruments where required. Finally the Sargan-Basmann test provides a measure of the adequacy and effectiveness of these instrumental variables to solve the problem (see Chang (2003) for full discussion of techniques). Firm and IPO control variables are as defined in previous sections.

\subsection{Determinants of Family firms}

Lastly I study the determinants of family firms and the factors that differentiate family firms from their non-family counterparts across the Maghreb region.

Given the North African region is dominated by family firms and an extended network of family and political ties business angel finance is likely to arise through the extension of family networks and is more likely to be positively associated with family as opposed to non-family firms (Chahine et al, 2007). However private equity and venture capital which is more formal and often involves foreign firms that are more intrusive in their control and involvement in business affairs are less likely to be involved in family firms (Chahine et al, 2007). Equally I conjecture that firms in large extractive industries such as mining and oil as well as in technology-related industries such as telecommunications are more likely to be former state owned enterprises rather than family controlled firms. However financial and manufacturing sector firms are more likely to be family firms given the breadth and diversity of these sectors in extending into microfinance and microcredit services. This results in the testing of five hypotheses:

H-7.1: The presence of private equity/ venture capital is less likely to be associated with family firms

H-7.2: The presence of business angels is more likely to be associated with family firms

H-7.3: Family firms are more likely to belong in finance industry 
H-7.4: Family firms are more likely to belong in Manufacturing industry

H-7.5: Family firms are less likely to belong in Mining and Oil industries

H-7.6: Family firms are less likely to belong in Technology and Telecommunications industry

These hypotheses are tested using logistic (Logit) regressions with the dependent variable being dichotomous taking the value of 1 for family firms and 0 otherwise. The Logit regression is of the form:

Dependent $t_{i}=$ Cons $\tan t+\beta_{\text {Variables }}$ Variables $+\beta_{\text {Firm Controls }}$ Firm Controls $+\beta_{\text {IPO }}$ IPO Controls C $_{i}$

Firm and IPO controls are defined in previous sections. Dichotomous pulse dummy variables are employed defining a firm belonging within mining and oil, manufacturing, finance and technology industries as well as the presence of foreign private equity/ venture capitalist and business angel investors.

\section{Empirical Results}

\subsection{Descriptive statistics}

Summary statistics of IPOs undertaken across North Africa are provided in Table 2. These reveal that there are considerable differences in the initial returns, otherwise known as underpricing or IPO discount, between each of the stock markets. The evidence suggests that the greatest level of underpricing occurs in Tunisia (11.7\%) and Egypt (8.8\%) with the least in Algeria (1.6\%). However the greatest differential in underpricing occurs between family and non-family controlled firms within the region as a whole. Levels of underpricing in family firms at $3.2 \%$ are substantially lower than non-family firms at $13.6 \%$ indicating that the retained presence of family groups acts as a governance mechanism in reducing informational asymmetries and associated monitoring costs. The evidence from Table 1 also indicates that large proportions of listings are from family-firms. This is also reflective of recent proactive marketing and investor awareness campaigns undertaken by the regions stock exchanges in order to attract both a greater number of listings but from a wider section of the local national economies (Hearn, 2010)

\section{Table 2}


The evidence so far suggests that considerable differences exist between national stock markets and between different groups within the wider Maghreb region. The evidence from Table 3 largely confirms these differences. This reveals that the highest number of differences in firm-characteristics occurs between Egypt and its North African neighbours of Tunisia and Morocco, while slightly fewer differences exist between Tunisia and Morocco. While there are no statistically significant differences between the costs of equity across the three countries, there are significant differences in underpricing between Tunisia and Morocco. The most notable difference between the three countries is in the level of contract enforcement with judicial process to close contracts taking 410 days in Egypt, 240 days in Morocco and least of all 27 days in Tunisia. These substantial differences in law enforcement underline the motivation for the inclusion of a contractlenforcement variable as a control in the later modelling we will employ in this study. A final notable difference between the three markets is the significantly lower level of retained founder ownership in Egypt as compared to either Tunisia or Morocco indicating that the latter markets attract a wider dispersion of firms with more being characterised as family-controlled SMEs.

The differences between family and non-family firms are also highlighted in Table 3 where the most significant differences are in levels of underpricing which is considerably greater in nonfamily as opposed to family firms. The differences in firm governance are also pervasive with nonfamily firms having significantly lower CEO, Executive and Non-executive director ownership indicating less participation of insiders in firm affairs in non-family firms. Furthermore governance is achieved in non-family firms by large corporate block-shareholders which is confirmed from the evidence in Table 3 as block-shareholder ownership is statistically significantly higher than in family firms. These results collectively reveal the differences between the two very different governance mechanisms employed in institutionally weak markets, namely that involving the employment of large block-shareholders and that involving concentration of family-ownership.

\section{Table 3}

\subsection{Board governance impact on performance}

The evidence from the regression results in Table 4 indicates that board size is positively and strongly related to underpricing with a large coefficient value. However there are critical differences between family and non-family firms with the board size effect in the former being statistically significant at a $5 \%$ confidence level this is markedly reduced in the latter non-family firms with the effect not being statistically significant in underpricing at 2 weeks and only marginally significant at $10 \%$ confidence level for underpricing at 4 weeks. These results would appear to confirm the hypothesized relationships inasmuch that smaller boards have greater interaction and coordination ability between directors and incumbent managers thus enhancing information transmission. However a critical difference between family and non-family firms is that the board size has a considerably greater 
impact on explanatory power of models in the former type of firm as opposed to the latter. In contrast to board size the coefficients for board independence are low in value and not statistically significant at any confidence level across family and non-family firms as well as underpricing at 2 and 4 weeks. These latter results regarding board independence are unexpected and largely refute the anticipated relationship with underpricing and asymmetric information.

\subsection{Lead manager effects on IPO firm underpricing}

The evidence from Table 4 regarding the impact on underpricing at both 2 and 4 weeks from the inclusion of lead managers with dominant market share, or reputation, or those that are foreign reveals that while the former has no statistically significant effects on underpricing the latter has a large negative and statistically significant relationship with underpricing. This would confirm the anticipated signalling of quality effects from an IPO firm's employment of a foreign lead manager. However while the negative sign of the lead manager reputation coefficient is as expected the lack of statistical significance at any confidence level is unexpected. A further difference between family and non-family firms is in the exceptionally high statistical significance of the foreign lead manager coefficient for non-family as opposed to family firms and in the enhanced explanatory power arising from the inclusion of this variable in the former in contrast to the latter.

\subsection{Business Angel and Private Equity effects on IPO firm underpricing}

The evidence from Table 5 reveals that as anticipated the signs of the coefficients for business angels and private equity are as expected with the former being negative indicating a net reduction in underpricing while the latter are positive indicating an increase in underpricing. However there are differences between family and non-family firms with business angel coefficients being both large in absolute size and statistically significant in the former in contrast to smaller size and no statistical significance in latter type of firm. Similarly private equity coefficients are larger and have much higher statistical significance in non-family firms than in family firms where the coefficients lack any significance. These results provide support for the enhanced benefits of relationship-based finance arising from extended family and personal networks involved in family firms while non-family firms benefit from the more traditional formalised finance of private equity and venture capitalists.

\subsection{Family control effects on performance}

The evidence regarding family control effects and their relationship to the reduction of asymmetric information and underpricing is less clear. The results in Table 5 would infer that as the ratio of family board members to total family participation in the firm increases underpricing decreases as anticipated. However this effect lacks statistical significance at confidence levels over $10 \%$. In contrast to this result the relationship between increased ratios of family board member ownership to 
total family ownership actually has a positive relationship with underpricing, although again at no discernable level of statistical significance. Although these effects are questionable in significance they would provide some indication that more concentrated ownership by board members in family firms has a detrimental effect on reduction of asymmetric information for investors while contrastingly a higher proportion of family board members without the concentrated ownership may have a positive impact in mitigating asymmetric information and reducing underpricing.

\subsection{Determinants of Family ownership}

The evidence from Table 6 reveals that as anticipated the coefficients for retained business angels, private equity and the ratio of family board members to total family involvement are negative. However only the relationship between family ownership and business angels and the ratio of family board members to total participation are statistically significant at the $0.005 \%$ confidence level. These also have much larger coefficients than that for private equity involvement and their inclusion in models causes substantial increases in explanatory power. As such this is the strongest evidence so far of the impact of extended family and personal networks and relationships on the governance of the family firm. Increased family concentrated ownership has a negative relationship to increased family presence at board level and equally has a negative relationship with increased participation of outside business angel investors. This would infer that optimal governance in family firms may be more dispersed family ownership tied to a greater concentration of family members at board level. An unusual finding at this stage is that unlike increased family participation at board level and the retention of private equity investors the retention of business angel investors causes a sign change and a dramatic decrease in statistical significance of director (executive and non-executive) and corporate block-shareholder ownership. This would imply that the involvement of business angels in a family firm is an intrusive mechanism of governance that transcends ownership and management at all levels and is more intrusive than either concentrated family board participation or the engagement of private equity.

\subsection{Family and corporate block ownership effects on performance}

The evidence from two stage least squares (2SLS) regressions in Table 7 reveals some weak support for the benefits of retained family ownership in mitigating informational asymmetry and reducing underpricing. The family ownership coefficient is very low in absolute size and as anticipated negative in value for underpricing over 4 weeks at a weak statistical significance of $10 \%$ while it is not significant for underpricing over 2 weeks. The results for retention of corporate blockshareholder ownership are unexpected as despite the lack of statistical significance and low size they are positive in direction indicating retained block-shareholder ownership acts to increase underpricing. This is unexpected in an business environment shaped by civil code law institutions (Boulton et al, 
2008) and is likely to be more reflective of a contrast between benefits of family and blockshareholder ownership. As such this would provide some support for the benefits of family ownership and participation in firms within business environments shaped by poor levels of investor protection and weak institutions.

\subsection{Determinants of Family firms}

The results from the logistic regression in Table 8 reveal that across the Maghreb region family firms are less likely to belong to the technology/ telecommunications industry at a statistical confidence level of $5 \%$ as anticipated. However while the coefficient for inclusion in the mining/ oil industry is also negative it is not statistically significant at any discernable confidence level. The coefficient on the inclusion in finance industry is positive as expected but also lacks statistical significance while unexpectedly the coefficient for inclusion in manufacturing industry is negative it also lacks any discernable statistical significance. However consideration of firm and IPO control variables indicates that levels of debt (or gearing) is likely to be considerable higher in family than non-family firms as are revenues and levels of proceeds raised from issue in relation to total firm assets. These are reflective of significant structural differences in balance sheets of family as opposed to non-family firms.

\section{Conclusions}

This study investigates the performance and characteristics affecting levels of underpricing in a comprehensive sample of IPO firms across the North African region for the period 2000 to 2009. There are considerable differences in the firm balance sheet, IPO characteristics and levels of ownership between the three major Maghreb markets of Egypt, Tunisia and Morocco while significant differences exist between family and non-family firms across the region with underpricing being much greater in the latter type of firm for both two and four weeks in duration.

The findings in this study lend support to the concept of enhanced firm governance derived from deep family involvement within the firm's organisational structure thus acting to reduce monitoring costs and asymmetric information and consequently underpricing. However there is a strong disparity between levels of concentrated family ownership at board level and the proportion of family board participation in relation to total family participation within firm. While the latter exerts a largely positive governance effect in reducing underpricing the latter has the opposite effect indicating that while concentrated family involvement at board level is beneficial a concentration in ownership is not. Consequently a desirable governance feature of family firms would be more dispersed ownership that would offer incentives for monitoring while a concentration of family at board level in terms of numbers acts as a device to facilitate the transmission of information. This is 
intuitive given that the evidence suggests that board size has a considerable positive relationship with underpricing inferring that smaller boards are beneficial in firm coordination and management.

The findings also reveal that in both family and non-family firms the employment of a foreign lead manager, or Chef de File, exerts a substantial signalling effect of quality that dramatically reduces underpricing. However the evidence does also suggest that business angels are best placed to exert optimal monitoring and surveillance and intrusive management governance in firms in excess of that that could be achieved through the firms engagement of formal private equity and venture capitalists. This would provide further support for the networked relationship-based finance mechanisms in business environments that are shaped by poor external investor protection and weak institutions. Overall while the study provides credible and revealing evidence into the nature of family firms in North Africa the low level of IPO activity merits the extension of such a study across the Middle East region. 


\section{References}

Andersen, R. C., \& Reeb, D. M. (2003). Founding family ownership and firm performance: Evidence from the S\&P 500. Journal of Finance, 58(3), 1301-1329

Barclay, M. J., \& Holderness, C. G. (1989). Private benefits from control of public corporations. Journal of Financial Economics, 25(2), 371-395

Bartholomeusz, S. \& Tanewski, G. A. (2006). The relationship between Family Firms and Corporate Governance. Journal of Small Business Management, 44(2), 245-267

Brav, A., \& Gompers, P. (2003). The role of lock-ups in initial public offerings. The Review of Financial Studies, 16, 1-29

Beck, T., Demirguc-Kunt, A., \& Levine, R. (2003). Law and finance: why does legal origin matter? Journal of Comparative Economics, 31, 653-675

Becker, G. S. (1981). A Treatise on the Family. Cambridge, MA: Harvard University Press.

Bergstrom, T. C. (1995). On the evolution of altruistic rules for siblings. American Economic Review, $85(5), 58-81$

Bertrand, M., Johnson, S., Samphantharak, K., \& Schoar, A. (2008). Mixing family with business: A study of Thai business groups and the families behind them. Journal of Financial Economics, $88,466-498$

Boulton, T. J., Smart, S. B., \& Zutter, C. J. (2009). IPO underpricing and international corporate governance. Journal of International Business Studies, 1-17

Brenes, E. R., Madriagal, K., \& Molina-Navarro, G. E. (2006). Family business structure and succession: Critical topics in the Latin American experience. Journal of Business Research, 59(3), 372-374

Bruton, G. D., Filatotchev, I., Chahine, S., \& Wright, M. (2009). Governance, Ownership Structure, and Performance of IPO Firms: The Impact of Different Types of Private Equity Investors and Institutional Environments. Strategic Management Journal, forthcoming

Burkart, M., Panunzi, F., \& Schleifer, A. (2003). Family firms. Journal of Finance, 58(5), 2167-2201

Carney, M. (1998). A management capacity constraint? Obstacle to the development off overseas Chinese family business. Asia-Pacific Journal of Management, 15(2), 137-162

Chahine, S. (2007). Corporate governance and firm value for small and medium sized IPOs. Swiss Society for Financial Market Research, 8(2), 143-159

Chang, S. (2003). Ownership structure, expropriation, and performance of group-affiliated companies in Korea. Academy of Management Journal, 46, 238-254

Chami, R. (1999). What's different about family business? Unpublished working paper, University of Notre-Dame And International Monetary Fund, Notre-Dame: IN

Chu, W. (2009). The influence off family ownership on SME performance: evidence from public firms in Taiwan. Small Business Economics, 33, 353-373 
Claessens, S., Djankov, S., \& Lang, L. H. P. (2000). The separation of ownership and control in East Asian corporations. Journal of Financial Economics, 58, 81-112

Dahawy, K. (2007). Developing Nations and Corporate Governance: The Story of Egypt. Unpublished working paper, American University in Cairo, Egypt.

DeAngelo, H., \& DeAngelo, L. (2000). Controlling stock-holders and the disciplinary role of corporate payout policy: a study of the Times-Mirror company. Journal of Financial Economics, 56(2), 153-207

Demsetz, H., \& Lehn, K. (1985). The structure of corporate ownership: Causes and consequences. Journal of Political Economy, 93(6), 1155-1177

El Mehdi, I. K. (2007). Empirical evidence on corporate governance and corporate performance in Tunisia. Corporate Governance, 15(6), 1429-1441

Fama, E. F., \& Jensen, M. C. (1983). Separation of ownership and control. Journal of Law and Economics, 26(2), 3011-325

Filatotchev, I, \& Bishop, K. (2002). Board Composition, Share Ownership, and "Underpricing" of UK IPO Firms. Strategic Management Journal, 23, 941-955

Filatotchev, I., Lien, Y-C., \& Piesse, J. (2005). Corporate governance and performance in publically listed, family-controlled firms: Evidence from Taiwan. Asia-Pacific Journal of Management, $22,257-283$

Gomez-Mejia, L., Nunez-Nickel, M., \&Gutierrez, I. (2001). The role of family ties in agency contracts. Academy of Management Journal, 44(1), 81-95

Hayek, F. A. (1960). The Constitution of Liberty. Chicago: University of Chicago Press

Hearn, B., Piesse, J., \& Strange, R. (2009). Overcoming financing constraints to corporate expansion: evidence from a company in an emerging Islamic market. Transnational Corporations, 18(3), $1-26$

Hearn, B. (2010). Costs of Equity in North Africa's equity markets: an Industrial Sector Study. Unpublished working paper, Cairo and Alexandria Stock Exchange Occasional Paper No. 8, Cairo: Egypt

Jensen, M. C., \& Meckling, W. (1976). Theory of the firm: managerial behavior, agency costs, and ownership structure. Journal of Financial Economics, 3, 305-360

Kaserer, C., \& Moldernhauer, B. (2008). Insider ownership and corporate performance; evidence from Germany. Review of Management Studies, 2, 1-35

Kepner, E. (1983). The family and the firm: A co-evolutionary perspective. Organizational Dynamics, 12(1), 57-70

Kets de Vries, M. F. R. (1993). The dynamics of family controlled firm: The good and bad news. Organizational Dynamics, 21(3), 59-71 
Kuran, T. (2004). 'Why the Middle East is economically underdeveloped: historical mechanisms of institutional stagnation.' Journal of Economic Perspectives, 18(3), 71-90.

Kuran, T. (2003). The Islamic Commercial Crisis: Institutional Roots of Economic Underdevelopment in the Middle East. The Journal of Economic History, 63(2), 414-446

Lansberg, I. S. (1983). Managing human resources in family firms: The problem of institutional overlap. Organizational Dynamics, 12(1), 39-46

La Porta, R., Lopez-de-Silanes, F., Schliefer, A., \&Vishny, R. (2000). Investor protection and corporate governance. Journal of Financial Economics, 58, 3-27

La Porta, R., Lopez-de-Silanes, F., Schliefer, A., \&Vishny, R. (1997). Legal Determinants of External Finance. The Journal of Finance, 52, 1131-1150

La Porta, R., Lopez-de-Silanes, F., Schliefer, A., \&Vishny, R. (1998). Law and Finance. Journal of Political Economy, 106(6), 1113-1155

La Porta, R., Lopez-de-Silanes, F., \& Schliefer, A. (1999). Corporate Ownership Around the World, The Journal of Finance, 24(2), 471-517

La Porta, R., Lopez-de-Silanes, F., \& Shleifer, A. (2008), The Economic Consequences of Legal Origins. Journal of Economic Literature, 46, 285-332

La Porta, R., Lopez-de-Silanes, F., Schliefer, A., \&Vishny, R. (2002). Investor Protection and Corporate Valuation. The Journal of Finance, 27(3), 1147-1170

Levine, R. (2005). Law, Endowments and Property Rights. Journal of Economic Perspectives, 19(3), 61-88

McConaughty, D., Walker, M., Henderson, G., \& Mishra, C. S. (1998). Founding family controlled firms: Efficiency and value. Review of Financial Economics, 7(1), 1-119

Morck, R. K., Shleifer, A., \& Vishny, R. (1988). Management ownership and market valuation; An empirical analysis. Journal of Financial Economics, 20(12),293-315

Morck, R. K., Strangeland, D. A., \& Yeung, B. (2000). Inherited wealth, corporate control, and economic growth: The Canadian disease. In R. K. Morck (Ed.). Concentrated corporate ownership (pp 319-369). Chicago: University of Chicago Press

North, D C (1991). Institutions. Journal of Economic Perspectives, American Economic Association, 5(1) 97-112

OECD (2007). Advancing the corporate governance agenda in the Middle East and North Africa: A survey of legal and institutional frameworks. OECD-MENA Investment Program, OECD: Paris

O’Hara, M. (2003) Presidential address: liquidity and price discovery. Journal of Finance, 58, 13351354

Perez-Gonzalez, F. (2002). Inherited Control and Firm Performance. Unpublished working paper, SSRN Working Paper, July, http://ssrn.com/abstract-320888 
Poza, E. J. (2007). Family business. New York: Thomson South-Western

Schleifer, A., \& Vishny, R. (1997). A survey of corporate governance. Journal of Finance, 52(2), 737 783

Schulze, E. S., Lubatkin, M. H., Dino, R. N., \& Bucholtz, A. K. (2001). Agency relationships in family firms: Theory and Evidence. Organization Science, 12, 99-116

Smith, G., \& Jefferis, K. (2005) The Changing Efficiency of African Stock Markets, South African Journal of Economics, 73(1), 54-67

Smith, B. F., \& Amoako-Adu, B. (1999). Management success and financial performance of family controlled firms. Journal of Corporate Finance, 5(4), 341-368

Thomsen, S., \& Pedersen, T. (2000). Ownership structure and economic performance in the largest European companies. Strategy Management Journal, 21(6), 689-7055

Williamson O E (2000). The new institutional economics: Taking stock, looking ahead. Journal of Economic Literature XXXVIII (September 2000) 595-613 
Table 1. Number of IPOs in North Africa by market

\begin{tabular}{|c|c|c|c|c|c|c|c|}
\hline \multirow[t]{2}{*}{ Year } & \multirow[t]{2}{*}{ Total } & \multirow[t]{2}{*}{ Algeria } & \multirow[t]{2}{*}{ Egypt } & \multirow[t]{2}{*}{ Tunisia } & \multicolumn{3}{|l|}{ Morocco } \\
\hline & & & & & $\begin{array}{l}\text { Marché } \\
\text { principal }\end{array}$ & $\begin{array}{l}\text { Marché } \\
\text { développement }\end{array}$ & $\begin{array}{l}\text { Marché } \\
\text { croissance }\end{array}$ \\
\hline 2000 & 4 & 2 & 1 & $\begin{array}{l}--- \\
\end{array}$ & 1 & -- -- & -- -- \\
\hline 2001 & 4 & -- -- & -- -- & 4 & -- -- & 2 & -- -- \\
\hline 2002 & 1 & -- -- & -- -- & 1 & -- -- & -- -- & -- -- \\
\hline 2003 & 1 & -- -- & -- -- & 1 & -- -- & -- -- & -- -- \\
\hline 2004 & 2 & -- -- & -- -- & -- -- & 2 & -- -- & -- -- \\
\hline 2005 & 10 & -- -- & 3 & 4 & 2 & 1 & -- -- \\
\hline 2006 & 13 & -- -- & 1 & 2 & 4 & 3 & 3 \\
\hline 2007 & 15 & -- -- & 2 & 4 & 5 & 3 & 1 \\
\hline 2008 & 10 & -- -- & 2 & 2 & 4 & 2 & -- -- \\
\hline 2009 & 1 & -- -- & -- -- & 1 & -- -- & -- -- & -- -- \\
\hline
\end{tabular}

Table 2. Distribution of IPOs, initial returns and cost of equity by country

This table presents the distribution of IPOs and initial returns statistics by listing country. Initial return is the secondary market closing price at end of second week of listing divided by the final offer price, minus 1 .

\begin{tabular}{|c|c|c|c|c|c|}
\hline \multirow[t]{2}{*}{$\overline{\text { Category }}$} & \multicolumn{5}{|c|}{ Initial Returns ( 2 weeks) } \\
\hline & $\mathbf{N}$ & $\mathbf{N}_{\mathbf{F F}}$ & Mean & Median & Std. dev. \\
\hline Egypt & 9 & 6 & 0.088 & 0.105 & 0.461 \\
\hline Morocco & 32 & 16 & 0.073 & 0.110 & 0.418 \\
\hline Tunisia & 18 & 10 & 0.117 & 0.200 & 0.452 \\
\hline Algeria & 2 & 0 & 0.016 & 0.016 & 0.022 \\
\hline Mean & 63 & 32 & 0.122 & 0.116 & 0.384 \\
\hline IPO Family controlled Firms & 32 & & 0.032 & 0.012 & 0.344 \\
\hline IPO non-Family-controlled Firms & 31 & & 0.136 & 0.122 & 0.313 \\
\hline
\end{tabular}

Notes: (1) $\mathbf{N}$ indicates number of IPO firms within category

(2) $\mathbf{N}_{\mathbf{F F}}$ indicates number of IPO firms controlled by family groups 
Table 3. Summary statistics for Firm characteristics at the time of IPO

The data have been sourced manually from the last prospectus lodged with the relevant securities exchange or national regulator immediately prior to listing. All financial variables are expressed either as ratios or in thousands of US dollars. Firm age is measured in years between inception and IPO date.

\begin{tabular}{|c|c|c|c|c|c|}
\hline \multirow[b]{2}{*}{ Market } & \multicolumn{3}{|c|}{ Country-level differences } & \multicolumn{2}{|c|}{ Firm-type differences } \\
\hline & Egypt & Tunisia & Morocco & Family Firm & Non-Family Firm \\
\hline \multicolumn{6}{|l|}{ Firm } \\
\hline Total Assets & $1,212,189.38 \mathbf{b}$ & $65,247.26$ & $434,212.59$ & $173,073.46$ & $647,608.07 *$ \\
\hline Total Debt & $571,147.57 \mathbf{b}$ & $39,666.33$ & $321,958.55$ & $119,719.55$ & $406,034.30$ \\
\hline Shareholders Equity & $633,354.95 \mathbf{a}, \mathbf{b}$ & $25,400.67$ & $104,245.75$ & $50,968.94$ & $233,119.04 *$ \\
\hline Revenue & $165,079.13$ & $989,456.47$ & $9,334,082.71$ & $9,814,545.17$ & $461,178.33$ \\
\hline Net Profits & $27,868.39 \mathbf{b}$ & $6,315.42$ & $3,570,847.01$ & $4,291,872.18$ & $244,928.69 *$ \\
\hline Total Debt/ Total Assets & $0.65 b$ & $0.46 \mathbf{c}$ & 0.57 & 0.55 & 0.57 \\
\hline Firm age & 36.78 & $20.58 \mathbf{c}$ & 33.88 & 29.25 & 30.54 \\
\hline Board Size & 13.44 & 7.95 & 10.70 & 8.91 & $12.23^{*}$ \\
\hline \multicolumn{6}{|l|}{ IPO } \\
\hline Cost of Equity & 17.50 & 12.90 & 11.94 & 12.71 & 13.05 \\
\hline Underpricing at 2 weeks & 8.76 & $4.50 \mathrm{c}$ & 13.19 & 3.19 & $13.58^{*}$ \\
\hline Underpricing at 4 weeks & 9.53 & $1.69 \mathrm{c}$ & 24.94 & 5.92 & $25.29 *$ \\
\hline \% Daily Zero Returns & $10.97 \mathbf{a}, \mathbf{b}$ & 32.89 & 22.60 & 23.85 & 28.50 \\
\hline Lead Manager Reputation & 36.51 & $56.75 \mathrm{c}$ & 21.24 & 35.08 & 38.24 \\
\hline Lead Manager Foreign & $0.44 \mathbf{b}$ & $0.00 \mathrm{c}$ & 0.21 & 0.19 & 0.16 \\
\hline Contract Enforcement (Days) & $410 \mathbf{a}, \mathbf{b}$ & $27 \mathbf{c}$ & 240 & 205.31 & 205.39 \\
\hline \multicolumn{6}{|l|}{ Ownership } \\
\hline$\%$ CEO Ownership Post IPO & 12.30 & 19.09 & 14.54 & 23.69 & $7.06+\dagger$ \\
\hline$\%$ Executives Ownership Post IPO & 18.53 & 20.78 & 20.68 & 29.49 & $10.64 \dagger \dagger$ \\
\hline$\%$ Non-Executives Ownership Post IPO & 5.41 & $17.60 \mathrm{c}$ & 6.94 & 15.13 & $4.63 * *$ \\
\hline$\%$ Founder Ownership Post IPO & $10.05 \mathbf{a}, \mathbf{b}$ & 40.01 & 48.61 & 46.30 & 24.85 \\
\hline$\%$ Business Angels Ownership Post IPO & 8.04 & 3.15 & 5.07 & 7.56 & $2.10 * *$ \\
\hline$\%$ Block Shareholder Ownership Post IPO & 43.53 & 34.41 & 41.78 & 23.36 & $59.25+\dagger$ \\
\hline$\%$ Private Equity/ Venture Capitalist & 17.85 & 22.05 & 26.96 & 15.30 & 28.74 \\
\hline
\end{tabular}

Notes: (1) Country-level differences: a Signifies difference between Egypt and Morocco at 10\% confidence level; b Signifies difference between Egypt and Tunisia at $10 \%$ confidence level; c Signifies difference between Tunisia and Morocco at $10 \%$ confidence level

(2) Firm-type differences: * Significant at $10 \%$ confidence level; ** Significant at 5\% confidence level; $\uparrow$ Significant at $1 \%$ confidence level;

$\dagger \dagger$ Significant at $0.5 \%$ confidence level 
Table 4. OLS regression analysis of board and lead manager characteristics on IPO Firm performance

The table presents the OLS estimates of the following regression equation:

Firm Underpricing ${ }_{i}=\beta_{\text {Characteristics }}$ Characteristics $+\beta_{\text {Firm }}$ Firm Controls $_{i}+\beta_{\text {IPO Variables }}$ IPO Variables Vir $_{i}+\varepsilon_{i}$

Characteristics are defined as Log Board Size s natural logarithm of board size, board Independence is ratio of nonexecutive to executive directors, or in the case of

supervisory boards the ratio of supervisory nonexecutive members to executive senior management, charged with running firm. Lead manager reputation is the cumulative market share of IPO proceeds raised by clients of the lead manager in relation to total IPO proceeds raised on local market while lead manager foreign is dichotomous pulse dummy variable taking value 1 if lead manager is foreign and 0 otherwise. Firm control variables are natural logarithm of tangible assets (in US\$), natural logarithm of firm age, itself the difference between foundation and listing date, natural logarithm of firm revenues in year preceding listing (in US\$) and ratio of total debt to total assets. IPO control sare natural logarithm of IPO proceeds to total assets (both in US\$), natural logarithm of IPO proceeds to tangible assets (both in US\$).

\begin{tabular}{|c|c|c|c|c|c|c|c|c|}
\hline \multirow[t]{3}{*}{ Independent Variables } & \multicolumn{4}{|c|}{$\begin{array}{l}\text { Family Firms } \\
\text { Dependent Variables }\end{array}$} & \multicolumn{4}{|c|}{ Non-Family Firms } \\
\hline & $\begin{array}{l}\text { Underpricing ( } 2 \\
\text { weeks) }\end{array}$ & $\begin{array}{l}\text { Underpricing ( } 2 \\
\text { weeks) }\end{array}$ & $\begin{array}{l}\text { Underpricing ( } 4 \\
\text { weeks) }\end{array}$ & $\begin{array}{l}\text { Underpricing ( } 4 \\
\text { weeks) }\end{array}$ & $\begin{array}{l}\text { Underpricing ( } 2 \\
\text { weeks) }\end{array}$ & $\begin{array}{l}\text { Underpricing ( } 2 \\
\text { weeks) }\end{array}$ & $\begin{array}{l}\text { Underpricing ( } 4 \\
\text { weeks) }\end{array}$ & $\begin{array}{l}\text { Underpricing ( } 4 \\
\text { weeks) }\end{array}$ \\
\hline & Model 1 & Model 2 & Model 3 & Model 4 & Model 5 & Model 6 & Model 7 & Model 8 \\
\hline Intercept & $-202.45(-1.34)^{*}$ & $-15.58(-0.17)$ & $-173.65(-1.20)$ & $5.81(0.06)$ & $-40.69(-0.62)$ & $\begin{array}{l}-85.55(-3.07) \\
\dagger \dagger\end{array}$ & $-121.95(-1.00)$ & $\begin{array}{l}-218.12(-5.93) \\
\dagger \dagger\end{array}$ \\
\hline \multicolumn{9}{|l|}{ Characteristics } \\
\hline Log Board Size & $117.01(1.69)^{* *}$ & & $114.44(1.84)^{* *}$ & & $16.52(0.94)$ & & $71.20(1.44)^{*}$ & \\
\hline Board Independence & $0.01(0.03)$ & & $-0.004(-0.01)$ & & $0.41(1.12)$ & & $0.11(0.15)$ & \\
\hline Lead manager reputation & & $-0.15(-0.80)$ & & $-0.18(-1.04)$ & & $-0.03(-0.30)$ & & $-0.06(-0.31)$ \\
\hline Lead manager foreign & & $-51.40(-2.07)^{* *}$ & & $-47.05(-1.68) * *$ & & $\begin{array}{l}-35.61(-4.44) \\
\dagger \dagger\end{array}$ & & $\begin{array}{l}-64.30(-9.53) \\
\dagger \dagger\end{array}$ \\
\hline \multicolumn{9}{|l|}{ Firm Controls } \\
\hline Log Tangible Assets & $43.28(1.70)^{* *}$ & $60.61(1.98)^{* *}$ & $42.76(1.71)^{* *}$ & $58.90(2.02)^{* *}$ & $14.81(1.36)^{*}$ & $26.85(2.46) \dagger$ & $26.43(1.13)$ & $37.69(2.81) \dagger \dagger$ \\
\hline Log Firm Age & $-14.46(-0.51)$ & $-56.18(-0.94)$ & $-33.92(-1.29)^{*}$ & $-74.49(-1.48)^{*}$ & $25.44(4.66) \dagger \dagger$ & $17.73(1.60)$ & $52.27(1.65)^{* *}$ & $49.51(1.64)^{* *}$ \\
\hline Log Revenue & $-22.35(-0.40)$ & $-58.65(-2.53) \dagger$ & $-27.81(-0.55)$ & $-64.74(-2.45) \dagger$ & $-33.35(-1.94)^{* *}$ & $-33.15(-1.93) * *$ & $-3.87(-0.11)$ & $5.31(0.20)$ \\
\hline Log Net Income & $-3.25(-0.04)$ & $17.07(0.62)$ & $2.86(0.04)$ & $25.25(0.83)$ & $20.55(1.79)^{* *}$ & $20.89(2.30)^{* *}$ & $-15.58(-0.54)$ & $-12.51(-0.64)$ \\
\hline Total Debt/ Total Assets & $-18.16(-0.36)$ & $-37.47(-0.66)$ & $-11.38(-0.23)$ & $-26.74(-0.52)$ & $-11.35(-1.14)$ & $-13.41(-1.13)$ & $-27.57(-0.92)$ & $-8.10(-0.29)$ \\
\hline \multicolumn{9}{|l|}{ IPO Variables } \\
\hline $\begin{array}{l}\text { Log IPO Proceeds/ Total } \\
\text { Assets }\end{array}$ & $14.96(0.74)$ & $-25.16(-1.54)^{*}$ & $13.28(0.73)$ & $-25.15(-1.48)^{*}$ & $28.47(4.98) \dagger \dagger$ & $2.78(0.60)$ & $62.45(2.38) \dagger$ & $24.44(1.43)^{*}$ \\
\hline $\begin{array}{l}\text { Log IPO Proceeds/ } \\
\text { Tangible Assets }\end{array}$ & $1.79(0.08)$ & $-5.39(-0.32)$ & $-10.11(-0.56)$ & $-15.69(-0.94)$ & $-2.73(-0.50)$ & $16.84(3.49) \dagger \dagger$ & $17.34(0.80)$ & $49.94(3.95) \dagger \dagger$ \\
\hline Fixed Effects & No & No & No & No & No & No & No & No \\
\hline Observations & 17 & 17 & 17 & 17 & 23 & 23 & 23 & 23 \\
\hline F probability & 1.9806 & 1.4700 & 2.3284 & 1.6738 & 1.8175 & 3.0041 & 1.7933 & 2.8516 \\
\hline F-test all coefficients $=0$ & 0.189 & 0.312 & 0.138 & 0.254 & 0.158 & 0.035 & 0.163 & 0.042 \\
\hline Adjusted R2 & 0.3555 & 0.2091 & 0.4276 & 0.2748 & 0.2506 & 0.4505 & 0.2450 & 0.4310 \\
\hline
\end{tabular}

Notes: $\quad(1) * \mathrm{p}<0.10 ; * * \mathrm{p}<0.05 ; \uparrow \mathrm{p}<0.01 ; \dagger \uparrow \mathrm{p}<0.005$. Standard errors are in parentheses

(2) White cross-section standard errors \& covariance (d.f. corrected) 
Table 5. OLS regression analysis of Business Angel, Private Equity and Family Control characteristics on IPO Firm performance The table presents the OLS estimates of the following regression equation:

Firm Underpricing ${ }_{i}=\beta_{\text {Characteristics }}$ Characteristics $+\beta_{\text {Firm }}$ Firm Controls $_{i}+\beta_{\text {IPO Variables }}$ IPO Variables V $_{i}+\varepsilon_{i}$

Firm controls and IPO variables are defined as in Table 4. Characteristics are defined with the two variables, business angel and private equity present as being dichotomous pulse dummy variables taking value 1 if condition is satisfied and 0 otherwise. The Ratio of Family board members to total family involvement is number of family

members on board to those involved (as owners, shareholders, supervisors etc) in firm, and ratio of family board ownership to total family ownership.

\begin{tabular}{|c|c|c|c|c|c|c|}
\hline \multirow[t]{4}{*}{ Independent Variables } & \multirow{2}{*}{\multicolumn{3}{|c|}{$\begin{array}{l}\text { Family Firms } \\
\text { Dependent Variables }\end{array}$}} & \multirow{2}{*}{\multicolumn{3}{|c|}{ Non-Family Firms }} \\
\hline & & & & & & \\
\hline & $\begin{array}{l}\text { Underpricing ( } 2 \\
\text { weeks) }\end{array}$ & $\begin{array}{l}\text { Underpricing ( } 2 \\
\text { weeks) }\end{array}$ & $\begin{array}{l}\text { Underpricing ( } 4 \\
\text { weeks) }\end{array}$ & $\begin{array}{l}\text { Underpricing ( } 4 \\
\text { weeks) }\end{array}$ & $\begin{array}{l}\text { Underpricing ( } 2 \\
\text { weeks) }\end{array}$ & $\begin{array}{l}\text { Underpricing ( } 4 \\
\text { weeks) }\end{array}$ \\
\hline & Model 9 & Model 10 & Model 11 & Model 12 & Model 13 & Model 14 \\
\hline Intercept & $-68.02(-0.78)$ & $-3.53(-0.03)$ & $-44.05(-0.49)$ & $17.74(0.18)$ & $-33.32(-0.69)$ & $-157.16(-1.68)^{* *}$ \\
\hline \multicolumn{7}{|l|}{ Characteristics } \\
\hline Business Angel present & $-35.47(-1.33)^{*}$ & & $-28.06(-1.03)$ & & $-5.59(-0.43)$ & $-19.46(-0.64)$ \\
\hline Private Equity present & $17.56(0.73)$ & & $12.77(0.52)$ & & $20.81(1.53)^{*}$ & $60.35(2.81) \dagger \dagger$ \\
\hline $\begin{array}{l}\text { Ratio of Family board members to } \\
\text { total family involvement }\end{array}$ & & $-27.90(-0.95)$ & & $-25.68(-0.89)$ & & \\
\hline $\begin{array}{l}\text { Ratio of family board ownership to } \\
\text { total family ownership }\end{array}$ & & $16.71(1.01)$ & & $17.30(1.08)$ & & \\
\hline \multicolumn{7}{|l|}{ Firm Controls } \\
\hline Log Tangible Assets & $34.02(1.39)^{*}$ & $38.31(1.33)^{*}$ & $35.14(1.41)^{*}$ & $37.78(1.31)^{*}$ & $29.76(8.53) \dagger \dagger$ & $45.75(3.21) \dagger \dagger$ \\
\hline Log Firm Age & $-7.61(-0.20)$ & $-20.50(-0.39)$ & $-28.71(-0.87)$ & $-40.78(-0.94)$ & $26.46(1.78)^{* *}$ & $70.32(2.14) * *$ \\
\hline Log Revenue & $-40.42(-1.41)^{*}$ & $-50.05(-1.52)^{*}$ & $-47.84(-1.67)^{* *}$ & $-55.13(-1.48)^{*}$ & $-38.72(-4.96) \dagger \dagger$ & $-3.68(-0.16)$ \\
\hline Log Net Income & $19.82(0.63)$ & $16.54(0.61)$ & $26.24(0.86)$ & $22.92(0.77)$ & $12.55(1.21)$ & $-30.38(-2.68) \dagger \dagger$ \\
\hline Total Debt/ Total Assets & $-6.03(-0.07)$ & $25.75(0.99)$ & $6.29(0.08)$ & $30.73(1.11)$ & $-9.74(-0.60)$ & $13.05(0.43)$ \\
\hline \multicolumn{7}{|l|}{ IPO Variables } \\
\hline Log IPO Proceeds/ Total Assets & $-18.28(-0.97)$ & $-13.53(-1.31)^{*}$ & $-18.10(-0.90)$ & $-14.24(-1.36)^{*}$ & $20.29(2.11)^{* *}$ & $52.34(2.07)^{* *}$ \\
\hline $\begin{array}{l}\text { Log IPO Proceeds/ Tangible } \\
\text { Assets }\end{array}$ & $8.64(0.55)$ & $-9.14(-0.68)$ & $-5.25(-0.31)$ & $-20.42(-1.72)^{* *}$ & $3.13(0.59)$ & $26.58(2.00)^{* *}$ \\
\hline Fixed Effects & No & No & No & No & No & No \\
\hline Observations & 16 & 16 & 16 & 16 & 23 & 23 \\
\hline F probability & 1.3150 & 1.0785 & 1.3368 & 1.3033 & 1.8993 & 3.4984 \\
\hline F-test all coefficients $=0$ & 0.381 & 0.471 & 0.373 & 0.371 & 0.142 & 0.020 \\
\hline Adjusted R2 & 0.1589 & 0.0422 & 0.1681 & 0.1457 & 0.2689 & 0.5054 \\
\hline
\end{tabular}

Notes: $\quad(1) * \mathrm{p}<0.10 ; * * \mathrm{p}<0.05 ; \dagger \mathrm{p}<0.01 ; \dagger \dagger \mathrm{p}<0.005$. Standard errors are in parentheses

(2) White cross-section standard errors \& covariance (d.f. corrected) 
Table 6. Regression analysis of factors affecting family share ownership

The table presents the OLS estimates of the following regression equation:

Family ShareOwnership $(\text { post }-I P O)_{i}=\beta_{\text {Characteristics }}$ Characteristics $+\beta_{\text {Firm Controls }}$ Firm Controls $+\beta_{\text {Firm Ownership }}$ Firm Ownership ${ }_{i}+\varepsilon_{i}$,

Characteristics are dichotomous variables, taking value 1 if condition is satisfied and 0 otherwise are: Business Angels Involvement, and Private Equity/ Venture Capital Involvement. Firm controls are defined in Table 4 and ratio of family board members to total family involvement is defined in Table 5. Firm ownership variables are postIPO Nonexecutive shareholding, Executive shareholding and Block-shareholder holding, which includes corporate and institutional shareholders.

Intercept

Characteristics

Ratio of Family board members to

total family involvement

Business Angels Involvement

Private Equity/ VC involvement

\section{Firm Controls}

Log Tangible Assets

Log Firm Age

Log Revenue

Log Net Income

Total Debt/ Total Assets

IPO Variables

Log IPO Proceeds/ Total Assets

Log IPO Proceeds/ Tangible Assets

\section{Firm Ownership}

Non-Executive holding post-IPO

Executive holding post-IPO

Block holding post-IPO

Ratio of Family bear
members to total
family involveme

Model 15

Business Angels Involvement

Model 16

$86.89(1.50)^{*}$

$-14.87(-1.95)^{* *}$

$-18.04(-1.90)^{* *}$

$-8.48(-1.23)$
$2.29(0.26)$
$24.76(1.26)$
$-25.39(-1.46)^{*}$
$12.63(0.66)$

$-23.46(-4.62) \dagger \dagger$

$21.72(4.76) \dagger \dagger$

$0.52(1.64)^{* *}$

$0.52(1.41)^{*}$

$0.36(1.22)$

\section{No}

18

Observations

F probability

F-test all coefficients $=0$

1.7799

0.247

0.3353

\section{$66.59(1.06)$}

$-4.05(-0.52)$

$8.86(0.74)$

$39.99(3.47) \dagger \dagger$

$-36.95(-3.28) \dagger \dagger$

$12.47(0.60)$

$-6.59(-0.64)$

$11.69(0.99)$

$-0.34(-0.52)$

$-0.57(-0.83)$

$-0.45(-0.84)$

No

17

1.9573

0.237

0.3969
Private Equity/VC Grand Regression

involvement

Model 17

$28.49(0.40)$

Model 18

$141.08(3.45) \dagger \dagger$

$-24.05(-3.69) \dagger$

$-23.39(-7.14) \dagger \dagger$

$-5.36(-1.21)$

$-4.72(-1.14)$

$-2.93(-0.33)$

$30.05(3.53) \dagger$

$-29.18(-3.50) \dagger \dagger$

$10.93(1.07)$

$-26.82(-2.60) \dagger$

$9.14(0.49)$

$\begin{array}{ll}-19.22(-3.82) \dagger \dagger & -4.79(-0.62) \\ 21.86(3.46) \dagger \dagger & 4.21(0.71)\end{array}$

$0.68(1.43) * \quad-0.57(-1.54) *$

$0.55(1.30) * \quad-0.70(-1.67)^{* *}$

$0.43(1.00) \quad-0.54(-1.23)$

No No

$17 \quad 17$

$\begin{array}{ll}1.3713 & 5.0253\end{array}$

$0.363 \quad 0.104$

$0.1937-0.7658$

Notes: $\quad(1) * \mathrm{p}<0.10 ; * \mathrm{p}<0.05 ; \dagger \mathrm{p}<0.01 ; \dagger \mathrm{p}<0.005$. Standard errors are in parentheses

(2) White cross-section standard errors \& covariance (d.f. corrected) 
Table 7. 2SLS regressions of Underpricing on Family control and Family-CEO status The table presents the 2SLS estimates of the following regression equation:

Firm Underpricing ${ }_{i}=\beta_{\text {Characteristics }_{\text {Characteristics }}+\beta_{\text {Firm }} \text { Firm Controls }_{i}+\beta_{\text {IPO Variables }} \text { IPO Variables }}+\varepsilon_{i}$ Underpricing is calculated from second and fourth weeks stock prices following listing. Firm and IPO control variables are defined in Table 4. Instrument variables are the number of business angel investors and three dichotomous variables indicating whether private equity/ venture capital was involved, whether founder retained role on board of directors and whether the lead manager was foreign.

\begin{tabular}{|c|c|c|}
\hline Independent Variables & $\begin{array}{l}\text { Dependent Variables } \\
\text { Underpricing (2 weeks) } \\
\text { Model } 5\end{array}$ & $\begin{array}{l}\text { Underpricing ( } 4 \text { weeks) } \\
\text { Model } 6\end{array}$ \\
\hline Intercept & $-62.74(-1.43)^{*}$ & $-128.94(-1.14)$ \\
\hline \multicolumn{3}{|l|}{ Characteristics } \\
\hline Family ownership (\%) IV & $-0.11(-0.33)$ & $-0.99(-1.61)^{*}$ \\
\hline Block ownership (\%) IV & $0.31(1.25)$ & $0.06(0.12)$ \\
\hline \multicolumn{3}{|l|}{ Firm Controls } \\
\hline Log Tangible Assets & $25.79(2.34) \dagger$ & $27.65(1.53)^{*}$ \\
\hline Log Firm Age & $22.04(1.41)^{*}$ & $55.93(2.05) * *$ \\
\hline Log Revenue & $-30.46(-1.97)^{* *}$ & $-3.17(-0.13)$ \\
\hline Log Net Income & $10.05(0.84)$ & $-10.65(-0.76)$ \\
\hline Total Debt/ Total Assets & $11.17(0.62)$ & $22.06(0.46)$ \\
\hline \multicolumn{3}{|l|}{ IPO Variables } \\
\hline Log IPO Proceeds/ Total Assets & $19.39(1.38)^{*}$ & $50.28(2.32) \dagger$ \\
\hline Log IPO Proceeds/ Tangible Assets & $6.19(1.33)^{*}$ & $18.31(1.16)$ \\
\hline Fixed Effects & No & No \\
\hline Observations & 40 & 40 \\
\hline F probability & 2.3228 & 1.7356 \\
\hline F-test all coefficients $=0$ & 0.040 & 0.124 \\
\hline Adjusted R2 & 0.1913 & 0.0816 \\
\hline
\end{tabular}

Notes: $\quad(1){ }^{*} \mathrm{p}<0.10 ;{ }^{*} \mathrm{p}<0.05 ; \dagger \mathrm{p}<0.01 ; \dagger \dagger \mathrm{p}<0.005$. Standard errors are in parentheses

(2) White cross-section standard errors \& covariance (d.f. corrected) 
Table 8. Determinants of family firms Logistic regressions

The table presents the 2SLS estimates of the following regression equation:

Dependent $t_{i}=$ Cons $\tan t+\beta_{\text {Variables }}$ Variables $+\beta_{\text {Firm Controls }}$ Firm Controls $+\beta_{\text {IPO IPO Controls }}+\varepsilon_{i}$

Dependent variable is dichotomous pulse dummy taking value 1 if family firm and 0 otherwise. Firm and IPO control variables are defined in Table 4 . All characteristic variables are dichotomous with business angels and private equity present taking value 1 if these investors have a retained presence and mining/ oil, finance, manufacturing and technology/ telecommunications taking value 1 if firm's primary activities are classed as falling within this industry sector.

\begin{tabular}{ll}
\hline Independent Variables & $\begin{array}{l}\text { Dependent Variables } \\
\text { Family/ Non-Family firm } \\
\text { Model } 5\end{array}$ \\
& \\
Intercept & $-10.18(-1.42)^{*}$ \\
Characteristics & $1.17(0.91)$ \\
Business Angel present & $-1.69(-1.16)$ \\
Private Equity present & $-1.45(-0.85)$ \\
Mining/ Oil Industry & $0.28(0.17)$ \\
Finance Industry & $-0.12(-0.06)$ \\
Manufacturing Industry & $-4.13(-1.80)^{* *}$ \\
Technology/ Telecommunications Industry & \\
Firm Controls & $-0.44(-0.35)$ \\
Log Tangible Assets & $-0.93(-0.53)$ \\
Log Firm Age & $3.16(1.58)^{*}$ \\
Log Revenue & $-1.27(-0.68)$ \\
Log Net Income & $4.99(1.74)^{* *}$ \\
Total Debt/ Total Assets & \\
IPO Variables & $4.02(2.01)^{* *}$ \\
Log IPO Proceeds/ Total Assets & $1.23(1.06)$ \\
Log IPO Proceeds/ Tangible Assets & \\
Observations & 41 \\
Obs. with Dep=0 & 23 \\
Obs. with Dep=1 & 18 \\
LR statistic & 23.096 \\
Probability (LR statistic) & 0.040 \\
McFadden R-squared & 0.4107 \\
\hline Notes: (1)*p<.10;**p<0.05; & \\
& \\
&
\end{tabular}

Notes: $\quad(1) * \mathrm{p}<0.10 ; * * \mathrm{p}<0.05 ; \dagger \mathrm{p}<0.01 ; \dagger \dagger \mathrm{p}<0.005$. Standard errors are in parentheses

(2) White cross-section standard errors \& covariance (d.f. corrected) 